\title{
Grapevine Downy Mildew Plasmopara viticola Infection Elicits the Expression of Allergenic Pathogenesis-Related Proteins
}

\author{
Giacomo Rossin $^{a}$ Danilo Villalta $^{\mathrm{b}}$ Paola Martelli $^{\mathrm{b}}$ Daniela Cecconi ${ }^{\mathrm{a}}$ \\ Annalisa Polverari ${ }^{a}$ Gianni Zoccatelli ${ }^{a}$ \\ ${ }^{a}$ Department of Biotechnology, University of Verona, Verona, and ${ }^{b}$ Unit of Allergy and Clinical Immunology, \\ A.O. S. Maria degli Angeli, Pordenone, Italy
}

\section{Key Words}

Grapevine $\cdot$ Vitis vinifera $\cdot$ Downy mildew Plasmopara viticola $\cdot$ Pathogenesis-related proteins $\cdot$ Proteomics - Mass spectrometry $\cdot$ Harpin-binding protein $\cdot \beta$-1,3-glucanase

\begin{abstract}
Background: Downy mildews are a group of microorganisms belonging to the Chromista kingdom that can infect specific plants. When growing on plant tissues these microbes can elicit the expression of pathogenesis-related proteins (PRs), a group of stress-induced proteins frequently described as allergens in many plant species. Our aim was to verify by a proteomic approach whether the allergic reactions experienced by a farmer working in a vineyard infected by Plasmopara viticola (Pv), the etiological agent of downy mildew, are elicited by PRs expressed by the grapevine upon infection or by allergens present in Pv. Methods: A skin prick test and prick-to-prick test with infected field grapevine leaves and control leaves were carried out. Field leaves and ad hoc PV-inoculated leaves were compared by SDS-PAGE and IgE-immunoblotting with extracts from control leaves
\end{abstract}

and Pv sporangia. IgE-binding proteins were further separated by two-dimensional electrophoresis and the positive spots analyzed by nanoHPLC-Chip and tandem mass spectrometry (MS/MS) for identification. Results: Only infected leaves showed lgE-binding protein bands at 42 and $36 \mathrm{kDa}$. This agreed with the positive skin prick test experienced by the patient only with the infected leaves extract. Two-dimensional electrophoresis followed by MS/MS analysis led to the identification of PR-2 ( $\beta$-1,3-glucanase) and harpinbinding protein 1 as putative allergens, the latter having never been reported before. Conclusion: The results indicate that Pv infection might represent a new source of plant allergens.

(c) 2015 S. Karger AG, Basel

\section{Introduction}

Cultivated grapevine is nowadays represented by the species Vitis vinifera, a plant native to Caucasus which has evolved over more than 100 million years. However, the history of viticulture is much more recent and began only

\section{KARGER 125}

(c) 2015 S. Karger AG, Base

$1018-2438 / 15 / 1682-0090 \$ 39.50 / 0$
Correspondence to: Dr. Gianni Zoccatell

Dipartimento di Biotecnologie

Università degli Studi di Verona

Strada Le Grazie, 15-CV1, IT-37134 Verona (Italy)

www.karger.com/iaa 
10,000 years ago. In terms of fruit production, grapevine represents one of the most cultivated fruit crops in the world.

Grapevine can mediate type- 1 allergic diseases, albeit less frequently than other plant species. Vine-associated respiratory symptoms have been described as being induced by pollens spread by vines during the pollination period in spring [1-3]. In a case report of a patient simultaneously allergic to vine pollen and berry, the IgE-binding proteins extracted from pollen were found to crossreact with grape proteins. However, vine allergens, inducing respiratory reactions, have not been identified so far. Besides pollen, aeroallergens associated with vine can be derived from different sources. A case report has been published of a patient experiencing respiratory symptoms induced by the vine-infecting mildew Plasmopara viticola $(\mathrm{Pv})$, the agent of downy mildew [4]. The patient was probably sensitized through working with the mildew in a greenhouse.

Although the authors demonstrated that the allergenic proteins were derived from $\mathrm{Pv}$, we cannot exclude that molds might induce the expression of allergenic proteins in vine. Indeed, it has recently been demonstrated that $\mathrm{Pv}$ induces the expression of pathogenesis-related proteins (PRs) in vine-infected leaves [5]. The objective of the present work was to verify by a proteomic approach whether the allergenic reactions experienced by a farmer working in a vineyard infected by $\mathrm{Pv}$ were elicited by PRs expressed upon infection or by allergens present in $\mathrm{Pv}$.

\section{Materials and Methods}

\section{Patient}

A 54-year-old man who worked in a vineyard infected with $P$. viticola and reported asthma episodes in August was recruited by the allergy division of the hospital of Pordenone. The patient tolerated the ingestion of grape berries as well as all varieties of wine. The patient underwent a clinical investigation by skin prick test (SPT) with a large range of commercial food (milk, egg, soy, wheat, chestnut, hazelnut, fish, shrimp, peach) and inhalant allergen extracts (grass, mugwort, ragweed, pellitory, plantain, birch, olive, cypress, mites, Alternaria alternata, cat and dog; Lofarma, Milan, Italy), by specific IgE assays for the most common pollen (ragweed, mugwort, grass, pellitory, plantain, birch, olive, cypress, saltwort, London plane) and mold (Aspergillus fumigatus, A. alternata, Cladosporium herbarum, Botrys cinerea) allergens, grape berries, peach nsLTP (Pru p 3) and PR-10 (Bet v 1; Thermofisher Scientific, Uppsala, Sweden), and by prick-to-prick test using infected and uninfected vine leaves previously ground and resuspended in a physiological solution.
Plant Material, Inoculum and Pathogen Infections

Infected and uninfected field vine leaves were collected in the vineyards close to the University building. Grapevine plants (cv pinot noir) were grown in vitro $\left(27^{\circ} \mathrm{C}, 16\right.$-hour photoperiod, $50 \mu \mathrm{E} / \mathrm{m}^{2} / \mathrm{s}$ ) as previously described [5]. The Pv inoculum was collected from infected field leaves and used for several artificial infection cycles on surface-sterilized leaves before the final inoculum was stored as sporangia at $-20^{\circ} \mathrm{C}$.

Leaves from in vitro plants were detached and placed in Petri dishes, abaxial side upwards, on a Whatman 3MM paper disk soaked in sterile distilled water. Each leaf was inoculated with a suspension of 30,000 sporangia per milliliter of sterile distilled water. Samples were incubated in a growth chamber $\left(24^{\circ} \mathrm{C}, 16\right.$-hour photoperiod, $50 \mu \mathrm{E} / \mathrm{m}^{2} / \mathrm{s}$ ) and two leaves from three different plants were collected at $96 \mathrm{~h}$ following infection. Control leaves were treated with water and maintained under the same conditions as inoculated leaves, and collected at the same time points. Samples were stored at $-80^{\circ} \mathrm{C}$ before processing.

\section{Protein Extraction}

The extraction of plant proteins was performed as previously described [5], with minor modifications, starting with both fieldand in vitro-cultivated leaves. Briefly, infected and uninfected leaves were ground under liquid nitrogen in the presence of a protease inhibitor cocktail ( $1 \times$ Complete Tablet; Roche Molecular Biochemicals, Mannheim, Germany) and 5\% PVPP (polyvinylpolypyrrolidone) to remove phenolic compounds. Proteins were extracted in five volumes of $7 \mathrm{M}$ urea, $2 \mathrm{M}$ thiourea, $80 \mathrm{mM}$ citric acid, $3 \%$ CHAPS, and incubated on ice for $2 \mathrm{~h}$ with regular vortexing and then centrifuged at $15,000 \mathrm{~g}$ for $30 \mathrm{~min}$ at $4^{\circ} \mathrm{C}$. The supernatant was then collected. Extracted proteins were precipitated with 4 volumes of cold acetone $\left(-20^{\circ} \mathrm{C}\right)$ overnight and pelleted by centrifugation $\left(15,000 \mathrm{~g}\right.$ for $15 \mathrm{~min}$ at $\left.4^{\circ} \mathrm{C}\right)$. Pellets were washed in acetone and then dissolved in $7 \mathrm{M}$ urea, $2 \mathrm{M}$ thiourea, 3\% CHAPS, $40 \mathrm{~mm}$ Tris, $1 \%$ DTT (dithiothreitol) and 1\% pH 3-10 ampholytes. The solutions were incubated on ice for $1 \mathrm{~h}$ and centrifuged $\left(15,000 \mathrm{~g}\right.$ for $15 \mathrm{~min}$ at $\left.4^{\circ} \mathrm{C}\right)$ to remove debris and nucleic acids. Sporangia were extracted with $1 \%$ SDS-5\% $\beta$-mercaptoethanol. Protein concentrations were estimated using Bradford assay (Sigma) by a microplate reader (Bio-Tek).

\section{SDS-PAGE}

The protein extracts were mixed with $2 \times$ loading buffer [62.5 $\mathrm{mM}$ Tris-HCl, pH 6.8, 1.3\% (w/v) SDS, and 10\% (w/v) glycerol, $4 \% \beta$-mercaptoethanol] and heated at $100^{\circ} \mathrm{C}$ for $5 \mathrm{~min}$. Proteins $(50 \mu \mathrm{g} / \mathrm{cm}$ of lane width) were separated in 16\% SDS-PAGE with a $20-\mathrm{mA}$ current by means of a Mini Protean III apparatus (BioRad, Hercules, Calif., USA) in $25 \mathrm{~mm}$ Tris, $192 \mathrm{mM}$ glycine and $0.1 \%$ SDS ( $\mathrm{pH}$ 8.4). The gels were stained with Coomassie R250 or alternatively blotted as described below.

\section{Two-Dimensional Electrophoresis (IPG X SDS-PAGE)}

Two-dimensional electrophoresis (2DE) separation was performed using 7-cm-long dry IPG strips ( $\mathrm{pH} 3-10$; Bio-Rad). The strips were actively rehydrated at $20^{\circ} \mathrm{C}$ by a Protean IEF Cell (Bio$\mathrm{Rad}$ ) for $12 \mathrm{~h}$ with a buffer containing $100 \mu \mathrm{g}$ of protein from the field-infected leaves. The focusing was then carried out until 25 $\mathrm{kVh}$ was reached. After focusing, the IPG gel strips were placed in a screw-cap tube containing $10 \mathrm{ml}$ of equilibration buffer $(0.375 \mathrm{M}$ Tris-HCl, pH 8.8, 6 M urea, 30\% glycerol, 2\% SDS, 20 mM DTT) 
and incubated for $15 \mathrm{~min}$. The solution was replaced by $10 \mathrm{ml}$ of $50 \mathrm{~mm}$ iodoacetamide-containing equilibration buffer. The strips were equilibrated for a further $15 \mathrm{~min}$. The second dimension SDS-PAGE was performed using a $12 \%$ polyacrylamide gel as previously described. Gels were alternatively stained with Coomassie G (EZBlue; Sigma Aldrich, St. Louis, Mo., USA) or blotted as described below.

\section{Immunoblotting}

Proteins separated by SDS-PAGE or 2DE were electroblotted onto polyvinylidene fluoride membranes (Millipore, Billerica, Mass., USA) at a constant voltage (50 V for $150 \mathrm{~min}$ ) and immunodetected with the patient's serum diluted 1:10 in blocking solution (3\% w/v of skimmed dry milk and $0.05 \%$ Tween-20 in PBS) overnight. As secondary antibody, a horseradish peroxidase-conjugated anti-human IgE (Southern Biotech, Birmingham, Ala., USA) diluted 1:1500 was used. Bound IgE was detected by chemiluminescence (Millipore) using a Chemidoc XRS (Bio-Rad) image-acquiring device.

\section{Mass Spectrometry}

In-Gel Digestion

Spots giving a positive signal by IgE-immunoblotting were carefully cut out from 2D Coomassie-stained gels and subjected to in-gel trypsin digestion according to Shevchenko et al. [6] with minor modifications. The gel pieces were swollen in a digestion buffer containing $50 \mathrm{mM} \mathrm{NH}_{4} \mathrm{HCO}_{3}$ and $12.5 \mathrm{ng} / \mu \mathrm{l}$ of porcine trypsin (Promega, Madison, Wisc., USA) in an ice bath. After 30 min the supernatant was removed and discarded, $20 \mu \mathrm{l}$ of $50 \mathrm{mM}$ $\mathrm{NH}_{4} \mathrm{HCO}_{3}$ were added to the gel pieces and digestion was allowed to proceed at $37^{\circ} \mathrm{C}$ overnight. The supernatant-containing tryptic peptides were dried by vacuum centrifugation. Prior to mass spectrometric analysis, the peptide mixtures were redissolved in $5 \mu \mathrm{l}$ of $2 \%$ acetonitrile and $0.1 \%$ formic acid.

\section{Peptide Sequencing by nanoHPLC-Chip Tandem Mass}

Spectrometry

Peptides from $5 \mu$ of each sample were separated by reversephase nanoHPLC-Chip technology (Agilent Technologies, Palo Alto, Calif., USA) online coupled with a 3D ion trap mass spectrometer (Esquire 6000; Bruker Daltonics, Bremen, Germany). The chip was composed of a Zorbax 300SB-C18 (150 mm $\times 75 \mu \mathrm{m}$, with a 5- $\mu \mathrm{m}$ particle size) analytical column and a Zorbax 300SBC18 (40 nl, $5 \mu \mathrm{m}$ ) enrichment column. The complete system was fully controlled by ChemStation (Agilent Technologies) and EsquireControl (Bruker Daltonics) software. The scan range used was from 300 to $1,800 \mathrm{~m} / \mathrm{z}$. For tandem mass spectrometry (MS/ MS) experiments, the system was operated with automatic switching between MS and MS/MS modes. The three most abundant peptides of each $\mathrm{m} / \mathrm{z}$ were selected to be further isolated and fragmented. The MS/MS scanning was performed in the normal resolution mode at a scan rate of $13,000 \mathrm{~m} / \mathrm{z}$ per second. A total of five scans were averaged to obtain an MS/MS spectrum. Database searches were conducted using the MS/MS ion search of Mascot against all entries of the nonredundant NCBI database with the following parameters: specific trypsin digestion, up to one missed cleavage; fixed and variable modifications, carbamidomethyl-Cys and oxidated-Met, respectively; peptide and fragment tolerances, \pm 0.9 and $\pm 0.9 \mathrm{Da}$, respectively, and peptide charges, $+1,+2$ and +3 . The protein spots were identified as being a 'significant hit'

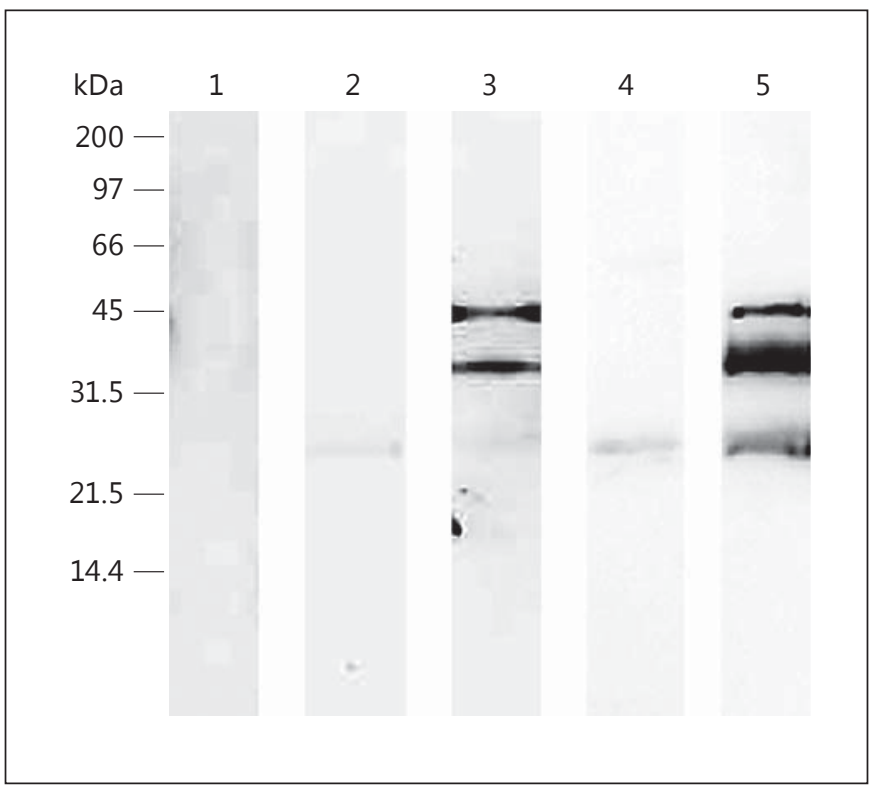

Fig. 1. SDS-PAGE and IgE immunoblotting of the extracts. $1=\mathrm{Pv}$; 2 and 3 = uninfected and infected leaves (from field plants); 4 and $5=$ uninfected and infected leaves (from in vitro plants).

$(\mathrm{p}<0.05)$ based on the individual peptide ion score. These peptide ion scores were automatically calculated by the Mascot program as $-10 \times \log (\mathrm{P})$, where $\mathrm{P}$ is the probability that the observed match is a random event.

\section{Results}

\section{Clinical Data}

SPT and specific IgE assays tested positive only for birch pollen and for its major allergen (PR-10; Bet v 1). The prick-to-prick test carried out with the infected leaves was positive while the uninfected leaves failed to induce skin reactions.

\section{The Infection of P. viticola Induces the Expression of}

\section{Different IgE-Binding Proteins}

The extracts obtained from the infected and uninfected vine leaves (both cultivated in the field and in in vitro) and from the mildew sporangia were compared by SDSPAGE and IgE immunoblotting with the patient serum (fig. 1). The results indicate that the allergens are intensely expressed by the plant upon infection (lanes 3 and 5) since no signals were detected in the Pv extract (lane 1) and only traces were found in uninfected leaves (lanes 2 and 4). Two major bands were detected by $\operatorname{IgE}$ at 42 and $35 \mathrm{kDa}$, showing the same detection pattern for the in- 


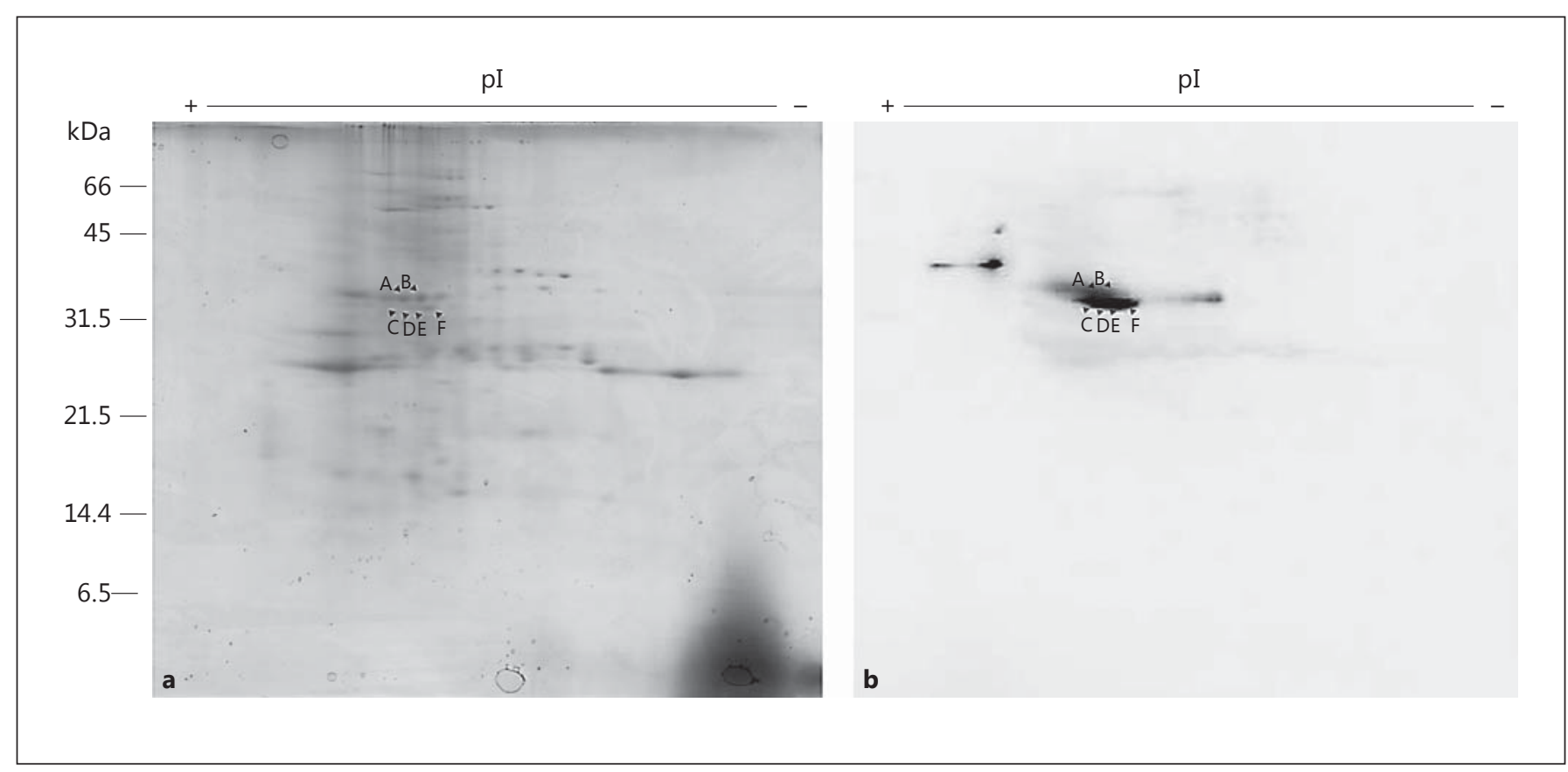

Fig. 2. $2 \mathrm{DE}$ of the infected leaves from field plants: Coomassie staining (a) and IgE immunoblotting with the patient's serum (b). pI = Isoelectric point.

Table 1. MS/MS results

\begin{tabular}{lllll}
\hline Spot & Protein name & Mr (theor.), Da & Mascot score & NCBI acc. No. \\
\hline A & B-1,3-glucanase (V. riparia) & 36,718 & 312 & gi:37992763 \\
B & B-1,3-glucanase (V. riparia) & 36,718 & 235 & gi:37992763 \\
C & HBP1 (Vitis sp. NL-2003) & 31,360 & 193 & gi:38679335 \\
D & HBP1 (Vitis sp. NL-2003) & 31,360 & 176 & gi:38679335 \\
& B-1,3-glucanase (V. riparia) & 36,718 & 165 & gi:37992763 \\
E & HBP1 (Vitis sp. NL-2003) & 31,360 & 147 & gi:38679335 \\
& B-1,3-glucanase (V. riparia) & 36,718 & 128 & gi:37992763 \\
F & HBP1(Vitis sp. NL-2003) & 31,360 & 159 & gi:38679335 \\
\hline
\end{tabular}

fected leaves collected from the field and after in vitro culture. A faint $24-\mathrm{kDa}$ band was detected in all vine samples, indicating that the related protein is not involved in the allergy manifestations. Interestingly, no bands at 20 $\mathrm{kDa}$, typical of Bet $\mathrm{v} 1$ homologues, have been detected despite birch SPT having tested positive.

\section{The IgE-Binding Proteins Are Defense Proteins}

The analysis of the 2D map of the extract of the infected leaves showed IgE-binding spots at different molecular masses. Due to the better resolving capacity of this ap- proach it was possible to distinguish two spot trains at 35.6 and $34 \mathrm{kDa}$ (fig. 2), whereas in the previous SDSPAGE these spots were comigrating in one band.

The results of the MS/MS analysis of the spots showing a positive signal in the immunoblotting are summarized in table 1 . The data indicate that the spot train at $35.6 \mathrm{kDa}$ (spots A and B) contains essentially $\beta$-1,3-glucanase (PR2 ), while the $34-\mathrm{kDa}$ train (spots $\mathrm{C}-\mathrm{F}$ ) is mainly composed of harpin-binding protein 1 (HBP1), even if some of the spots (spots $\mathrm{D}$ and $\mathrm{E}$ ) contain $\beta$-1,3-glucanase, probably due to an imperfect separation of the two pro- 
teins (spot D and E). The MS analysis of the $42-\mathrm{kDa}$ spot did not lead to any identification, probably as a consequence of the scarce protein concentration.

\section{Discussion}

PRs are part of an inducible plant defense system against pathogen attacks (e.g. bacteria, fungi, etc.) $[7,8]$ or abiotic stresses [9]. Different PR families have been described so far and, in parallel, it has been demonstrated that several of these families include proteins capable of eliciting allergic reactions. This is probably due to their higher stability and resistance to proteases in comparison to ordinary proteins [10]. In the present work we demonstrated that upon infection with $P$. viticola, specific IgEbinding proteins belonging to the PR-2 family ( $\beta-1,3-$ glucanases) and - to the best of our knowledge for the first time - to HBP1, are expressed. While $\beta$-1,3-glucanases have been extensively described as allergens, no record describing the potential allergenicity of HBP1s has been found. The targets of HBP1 are harpins [11], protein elicitors produced by a number of phytopathogenic bacteria $[11,12]$, that are considered virulence factors and can induce a strong hypersensitive reaction in plant tissues. HB$\mathrm{P} 1 \mathrm{~s}$ are expressed upon bacterial infection, but, in general, their upregulation can be also be a consequence of different stress conditions or treatments independent of the presence of harpin $[13,14]$. This correlates with our findings since $\mathrm{Pv}$ infection carried out under controlled conditions, and thus in the absence of evident bacterial growth, produced the same results observed in the fieldcultivated leaves. It is interesting that the action of dufulin, an inducer of systemic acquired resistance in plants, is based on the activation of HBP1 [15]. The same ap- proach has been described to enhance the expression of PRs like PR-1, PR-2 and PR-5 in the very commonly used model plant Arabidopsis thaliana [16]. For this reason, we cannot exclude that the use of such resistance inducers can increase the allergenic potency of some crops.

Despite the great number of works describing the induction of PRs due to biotic and abiotic stresses, only a few of them analyzed the IgE binding pattern and the allergenic potency of these proteins, and the results are in some cases contrasting. Sanchez-Monge et al. [17] described the induction of a class 1 chitinase after ethylene treatment of green bean. Similarly, ethylene associated to tissue wounding provoked an increase of the allergenic potency of turnip by inducing the expression of a prohevein [18]. Another example is given by the work of Mayer et al. [19], who demonstrated the increase of Mal $\mathrm{d} 1$ gene transcription and protein accumulation after infection by Erwinia amylovora. In contrast, a recent publication [20] showed that the infection of tomato by Pepino mosaic virus, despite inducing the overexpression of specific allergenic proteins, did not lead to a parallel increase of the allergenic potency of the fruit, analyzed by basophil activation test.

In our case, an SPT performed with the extracts of the infected leaves clearly induced a skin reaction in comparison to the uninfected leaves, suggesting that the IgEbinding proteins contained are also characterized by allergenic potency. The sensitization route remains elusive. We can suggest that this might be mediated by skin contact, as frequently described for $\beta$-1,3-glucanase in latexfruit syndrome [21]. We also cannot exclude that some leaf particles, perhaps from the necrotic tissues very prone to fragment and characterized by the highest allergen concentration, might have been inhaled by the subject during operations such as harvesting, thus representing the most likely means of exposure.

\section{References}

1 Mur P, Brito FF, Bartolome B, Galindo PA, Gomez E, Borja J, Alonso A: Simultaneous allergy to vine pollen and grape. J Investig Allergol Clin Immunol 2006;16:271-273.

2 Brito FF, Martinez A, Palacios R, Mur P, Gomez E, Galindo PA, Borja J, Martinez J: Rhinoconjunctivitis and asthma caused by vine pollen: a case report. J Allergy Clin Immunol 1999;103:262-266.

3 Brito FF, Gimeno PM, Bartolome B, Alonso AM, Lara P, Fernandez JA, Martinez A: Vine pollen allergy in areas with a high density of vineyards. Ann Allergy Asthma Immunol 2008;100:596-600.
4 Schaubschlager WW, Becker WM, Mazur G, Godde M: Occupational sensitization to Plasmopara viticola. J Allergy Clin Immunol 1994;93:457-463.

5 Milli A, Cecconi D, Bortesi L, Persi A, Rinalducci S, Zamboni A, Zoccatelli G, Lovato A, Zolla L, Polverari A: Proteomic analysis of the compatible interaction between Vitis vinifera and Plasmopara viticola. J Proteomics 2012; 75:1284-1302.

6 Shevchenko A, Wilm M, Vorm O, Mann M: Mass spectrometric sequencing of proteins silver-stained polyacrylamide gels. Anal Chem 1996;68:850-858.
7 van Loon LC: Pathogenesis-related proteins. Plant Mol Biol 1985;4:111-116.

8 Rigden J, Coutts R: Pathogenesis-related proteins in plants. Trends Genet 1988;4:87-89.

9 Lee BR, Jung WJ, Lee BH, Avice JC, Ourry A, Kim TH: Kinetics of drought-induced pathogenesis-related proteins and its physiological significance in white clover leaves. Physiol Plant 2008;132:329-337.

10 Hoffmann-Sommergruber K: Plant allergens and pathogenesis-related proteins: what do they have in common? Int Arch Allergy Immunol 2000;122:155-166. 
11 Choi MS, Kim W, Lee C, Oh CS: Harpins, multifunctional proteins secreted by Gramnegative plant-pathogenic bacteria. Mol Plant Microbe Interact 2013;26:1115-1122.

12 Wei ZM, Laby RJ, Zumoff CH, Bauer DW, He SY, Collmer A, Beer SV: Harpin, elicitor of the hypersensitive response produced by the plant pathogen Erwinia amylovora. Science 1992;257:85-88.

13 Wang R, Gao F, Guo BQ, Huang JC, Wang L, Zhou YJ: Short-term chromium-stress-induced alterations in the maize leaf proteome. Int J Mol Sci 2013;14:11125-11144.

14 Sarkar A, Rakwal R, Agrawal SB, Shibato J, Ogawa Y, Yoshida Y, Agrawal GK, Agrawal M: Investigating the impact of elevated levels of ozone on tropical wheat using integrated phenotypical, physiological, biochemical, and proteomics approaches. J Proteome Res 2010; 9:4565-4584.
15 Chen Z, Zeng MJ, Song BA, Hou CR, Hu DY, Li XY, Wang ZC, Fan HT, Bi L, Liu JJ, Yu DD, Jin LH, Yang S: Dufulin activates HrBP1 to produce antiviral responses in tobacco. PLoS One 2012;7:e37944.

16 Dong HS, Delaney TP, Bauer DW, Beer SV: Harpin induces disease resistance in Arabidopsis through the systemic acquired resistance pathway mediated by salicylic acid and the NIM1 gene. Plant J 1999;20:207-215.

17 Sanchez-Monge R, Blanco C, Perales AD, Collada C, Carrillo T, Aragoncillo C, Salcedo G: Class I chitinases, the panallergens responsible for the latex-fruit syndrome, are induced by ethylene treatment and inactivated by heating. J Allergy Clin Immunol 2000;106: 190-195.
18 Hanninen AR, Mikkola JH, Kalkkinen N, Turjanmaa K, Ylitalo L, Reunala T, Palosuo T: Increased allergen production in turnip (Brassica rapa) by treatments activating defense mechanisms. J Allergy Clin Immunol 1999;104:194-201.

19 Mayer M, Oberhuber C, Loncaric I, Heissenberger B, Keck M, Scheiner O, HoffmannSommergruber K: Fireblight (Erwinia amylovora) affects Mal d 1-related allergenicity in apple. Eur J Plant Pathol 2011;131:1-7.

20 Welter S, Dolle S, Lehmann K, Schwarz D, Weckwerth W, Worm M, Franken P: Pepino mosaic virus infection of tomato affects allergen expression, but not the allergenic potential of fruits. PLoS One 2013;8:e65116.

21 Wagner S, Breiteneder H: The latex-fruit syndrome. Biochem Soc Trans 2002;30:935-940. 